\title{
Test of Serum Immunoglobulin (Ig) of Newborn Kids by Anhydrous Sodium Sulphate
}

Jin MyongIl ${ }^{1}$, Choe SunIl ${ }^{1}$, Kim YunChol ${ }^{2}$, Ri SongGil ${ }^{3}$, Kim MyongGuk ${ }^{1}$, Hong SongDu ${ }^{1}$, Ra KiChol ${ }^{1}$

${ }^{1}$ Veterinary and Animal Husbandry Department, Sariwon Kye UngSang University of Agriculture, Pyongyang, 950003, DPR of Korea

2Institute of Genome, Branch of Biotechnology, State Academy of Sciences, Pyongyang, 950003, DPR of Korea

${ }^{3}$ Animal Husbandry institute, Academy of agriculture, Pyongyang, 950003, DPR of Korea

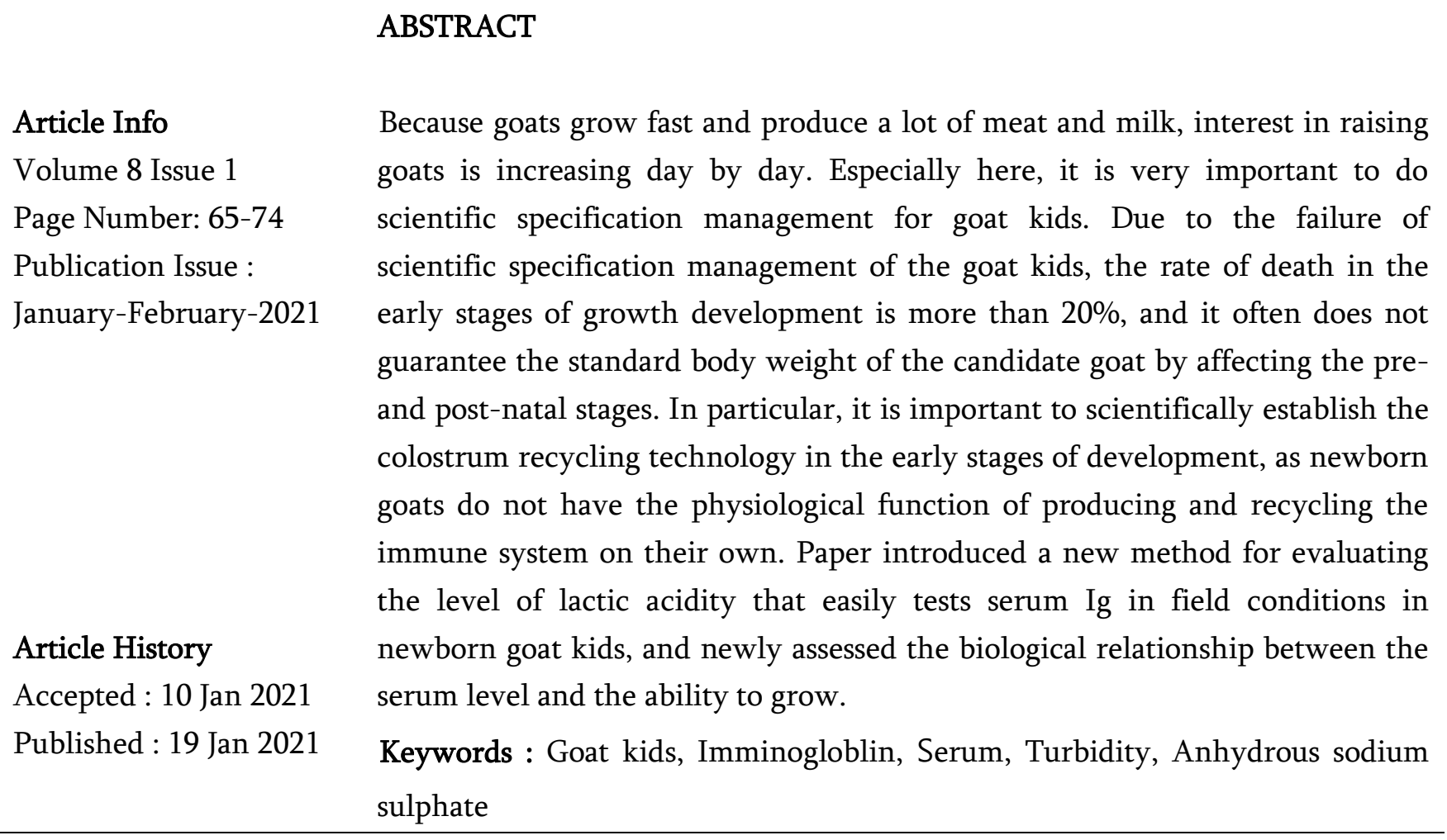

\section{INTRODUCTION}

Research projects on goat raising are becoming more active, and systematic research projects have been carried out since the goat kid stage. Studies of the composition of the colostrum and the role of immunogloblin show that the colostrum contains enough rare nutrients and growth factors and contains sex hormones such as progesterone and estrogen. The total total serum protein, total globlin and total albumin content of the goat kid are 6.4 to $7.0 \mathrm{~g} / \mathrm{dL}, 2.7$ to $4.1 \mathrm{~g} / \mathrm{dL}$, and 2.7 to $3.9 \mathrm{~g} / \mathrm{dL}$, respectively [1].The colostrum is 1.5 to 2 times more dry matter, 7 to 10 times more B12 and 2 to 3 times more vitamin $\mathrm{E}$ than ordinary milk. Normal albumin in chlorine: Globlin has a ratio of 0.63 to 1.26 and his variation is very wide [2]. According to the study, the serum Ig content of the goat kid 18 hours after 
feeding its colostrum was $735 \mathrm{mg} / \mathrm{dL}$ [3]. The serum Ig content of the mother's colostrum and young goat is closely related [4]. Goat milk has high fat rates, small fat districts, high levels of free fatty acids, and high levels of vitamins and minerals [5]. Goat milk differs from cow milk and sheep milk in physical characteristics such as viscosity, surface tension, and electrical conductivity. The ratio of low-grade saturated fatty acids in goat milk is 16.6 percent, more than double that of cow milk (7.2\%) [6]. One of the important characteristics of goat milk is that it is especially rich in the precursor to vitamin A [7]. The health and viability of goats kids are related to the transmission of mother antibodies through the colostrum at birth [8]. The critical period of feeding the colostrum is two to three days after birth, and the colostrum contains six to 6.5 times more protein than normal milk, which is mainly related to the presence of lactoglobulin. Twenty hours after birth, the valve permeability of immunoglobin is reduced and the immune function is lost because it is absorbed by the gastrointestinal tract like proteins with mass of giant molecules [9]. At the end of the 20th century, a researcher said that serum antibodies can be analyzed by neutral salt separation method, ribanol-salt separation method, low-temperature ethanol fractional method, low-ion isoelectric precipitation method, enzyme blood treatment method, ion exchange chromatograph analysis method, cephadex gel-filtration method, electrophoretic analysis, and ultra-primary precipitation method [10]. The concentration of the circulatory antibody is closely related to the health of the calf and reflects the sufficient intake of quality colostrum. The serum globlin precipitates well when it reacts to various salts.
In particular, the sodium sulfate solution works to uniquely precipitate immunoglobin, and at low concentrations, protein is not deposited, but if the concentration is high, the non-immune globlin protein is deposited. In the same way, we established a method for testing serum turbidity by an anhydrous sodium sulphate based on sufficient research and analysis of the prior researchers' literature to improve the scientification of young goat raising and to ensure practicality of goat raising.

\section{MATERIALS AND METHODS}

\subsection{Materials}

\section{1) Research conditions}

(1) Weather conditions

The accumulative temperature of over $5^{\circ} \mathrm{C}$ per year is $4030^{\circ} \mathrm{C}$, and its duration is from March 26th to November 12 November.

The accumulated temperature above $10^{\circ} \mathrm{C}$ is $3740^{\circ} \mathrm{C}$ between April 12 and October 25.

The annual precipitation was 850 to $900 \mathrm{~mm}$, the annual minimum temperature was $-22^{\circ} \mathrm{C}$, and the maximum temperature was 33 to $35^{\circ} \mathrm{C}$.

\section{(2) Specification management conditions}

The mother goat gave birth between early April and early May, feeding mixed food which consisted of maize $30 \%$, rice bran $40 \%$, maize or barley straw $20 \%$, cotton cake 5 to $7 \%$, and rest 3 to $5 \%$.

The nutritional value of $1 \mathrm{~kg}$ of mixed food was $10.02 \mathrm{MJ}$ of metabolism and $111.0 \mathrm{~g}$ of crude protein.

Table 1. Daily feeding capacity and nutritional value of mother goats

\begin{tabular}{c|c|c|c|c}
\hline Food & Unit & Quantity & $\begin{array}{c}\text { Metabolic energy, } \\
\text { MJ }\end{array}$ & $\begin{array}{c}\text { Crude protein, } \\
\mathrm{g}\end{array}$ \\
\hline Mixed food & $\mathrm{kg}$ & 0.3 & 3.01 & 33.3 \\
\hline Maize ensilage & $\mathrm{kg}$ & 4.0 & 11.36 & 83.2 \\
\hline
\end{tabular}




\begin{tabular}{r|l|l|l|l}
\hline Total & & 4.3 & 14.37 & 116.5 \\
\hline
\end{tabular}

\section{2) Materials}

\section{(1) Population of goat}

The number of goat kids used in the study was 98 Saanen, 393 hybrid, and the rest were Saanen hybrid breeds. 108 were used for basic tests to study the immunogloblin content and 252 for serum turbidity tests.

\section{(2) Variety and sex}

The goat kids used in the study were either a breeds of native or a hybrid of Saanen.

The native breed was white and weighed 38 to $45 \mathrm{~kg}$ after birth.

The goat kids did not take sex into account, and the ratio of the male to female was 1:1.

\section{(3) Study target type}

The primary target of the study is the serum immunoglobin (Ig) of the goat kids.

In the process of analyzing Ig content, albumin, globlin $(\alpha, \beta, \gamma)$ and total protein content was evaluated.

In conjunction with the Ig content, the body weight of the goat kids was measured by age during the feeding period and the weaning survival rate was analyzed and evaluated.

\subsection{Methods}

(1) Sampling and preservation method

Blood was drawn from the neck vein of the goat kids 48-96 hours after birth. The amount of the specimen was 3 to $5 \mathrm{ml}$ per head. The collected sample was centrifuged from 2000 to 2500 times per minute with a centrifuge within 12 hours, and the serum of the supernatant was collected and reused as an analysis sample.

\section{(2) Method for analyzing serum Ig concentration}

The Ig concentration of serum was analyzed by using the filter paper horizontal electrophoresis method and photoelectric color method. The filter paper FN-4 was installed on the OE-201 horizontal motor (OE-201) by cutting it $1.5 \mathrm{~cm}$ wide and planting $0.02 \mathrm{~mL}$ of serum per 1fi of filter paper at the starting line. Filter paper, which finished its operation, was dyed amide black $10-\mathrm{B}$ and cut by fraction to extract $0.01 \mathrm{~N}$ caustic soda solution, and then colored with a photoelectric color system (581-type) to obtain absorbance and Ig content.

$$
\text { Relative content of } \gamma \text {-globlin }=\frac{r-\text { extinction }}{\text { total extinction }} \times 100
$$

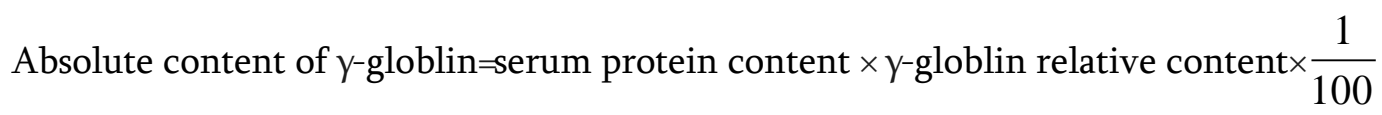

(3) Methods of body weight investigation of goat kids

The kids body weight was accurately measured on a scale on the day it was born up to two months of age every 10 days after its birth.

\section{芋. Results}

\subsection{Goat kids raising status}

In order to check the actual condition of raising a goat kids under different management levels, the body weight size and rate of raising a goat kids were investigated.

(1) Body weight of the goat kids 
Goats show a general characteristic of growing up early in kids and gradually slowing down as they grow older, but his variation varies greatly due to the nutrition of genetic and non-genetic factors such as variety and specification levels.

The size of the kids body weight at the Bongsan goat poultry in the DPR of Korea is as follows (Table 2).

Table 2. The body weight of goat kids by age

\begin{tabular}{|c|c|c|c|c|c|c|c|c|c|c|c|c|c|}
\hline \multirow[b]{2}{*}{ Group } & \multirow[b]{2}{*}{ Sex } & \multicolumn{3}{|c|}{ At birth } & \multicolumn{3}{|c|}{1 month old } & \multicolumn{3}{|c|}{2 months old } & \multicolumn{3}{|c|}{3 months old } \\
\hline & & $\begin{array}{c}\text { Population, } \\
\mathrm{n}\end{array}$ & Average & Amplitude & $\mathrm{n}$ & $\mathrm{M}$ & $\mathrm{L}_{1}-\mathrm{L}_{2}$ & $\mathrm{n}$ & $\mathrm{M}$ & ${\mathrm{L} 1-\mathrm{L}_{2}}_{2}$ & $\mathrm{n}$ & $\mathrm{M}$ & ${\mathrm{L} 1-\mathrm{L}_{2}}_{2}$ \\
\hline \multirow{2}{*}{$\begin{array}{l}\text { Native } \\
\text { breed }\end{array}$} & Male & 71 & 24 & $1.7 \sim 38$ & 59 & 5.2 & $3.6 \sim 6.0$ & 55 & 8.1 & $5.8 \sim 95$ & 51 & 9.9 & $65 \sim 172$ \\
\hline & Female & 56 & 2.3 & $1.6 \sim 33$ & 42 & 4.9 & $35 \sim 5.8$ & 40 & 7.0 & $52 \sim 8.9$ & 38 & 9.7 & $6.0 \sim 15.0$ \\
\hline \multirow{2}{*}{ F1-hybrid } & Male & 59 & 26 & $15 \sim 40$ & 36 & 5.7 & $29 \sim 8.1$ & 34 & 8.9 & $6.0 \sim 14.0$ & 34 & 10.9 & $7.0 \sim 19.0$ \\
\hline & Female & 39 & 24 & $1.4 \sim 40$ & 18 & 5.3 & $3.4 \sim 85$ & 18 & 7.3 & $5.0 \sim 13.0$ & 17 & 10.9 & $7.0 \sim 16.0$ \\
\hline \multirow{2}{*}{ Saanen } & Male & 164 & 3.2 & $27 \sim 48$ & 112 & 8.9 & $3.8 \sim 15.0$ & 80 & 12.8 & $6.3 \sim 19.0$ & 75 & 16.8 & $105 \sim 220$ \\
\hline & Female & 163 & 3.0 & $20 \sim 47$ & 124 & 75 & $32 \sim 11.0$ & 80 & 11.9 & $75 \sim 185$ & 77 & 14.1 & $85 \sim 21.0$ \\
\hline
\end{tabular}

As shown in Table 2, body weight by age of three months showed significant differences depending on breed. In particular, body weight is important at birth, and the correlation between birth weight and adult body weight is not deep, but it greatly affects the rate of growth. The body weight of native $\times$ Saanen F1 Goat kids raised under the conditions of the goat's stocking is as follows.

Table 3. Body weight of native $\times$ Saanen F1 Goat kids (kg)

\begin{tabular}{c|c|c|c|c|c|c|c|c}
\hline \multirow{2}{*}{ Sex } & \multicolumn{2}{|c|}{ At birth } & \multicolumn{2}{c|}{1 month old } & \multicolumn{2}{c|}{2 months old } & \multicolumn{2}{c}{3 months old } \\
\cline { 2 - 9 } & Population & $\begin{array}{c}\text { Body } \\
\text { weight }\end{array}$ & Population & $\begin{array}{c}\text { Body } \\
\text { weight }\end{array}$ & Population & $\begin{array}{c}\text { Body } \\
\text { weight }\end{array}$ & Population & $\begin{array}{c}\text { Body } \\
\text { weight }\end{array}$ \\
\hline Male & 32 & 2.7 & 28 & 6.3 & 27 & 9.1 & 24 & 12.3 \\
\hline Female & 34 & 2.5 & 30 & 5.9 & 28 & 8.7 & 23 & 11.8 \\
\hline
\end{tabular}

As shown in table 3, the kids raised at Sohung breeding stock farm were not very large and weighed about 12 $\mathrm{kg}$ at the age of three months.

(2) Growth degree of goat kids at the production site

As shown in Table 4, the raising rate of goat kids was low in the range of $63.4^{\sim} 76.1 \%$.

Table 4 . The goat kids growth degree

\begin{tabular}{c|c|c|c|c}
\hline Production units & Population & Survival & Raising rate (\%) & $\begin{array}{c}\text { Mortality rate } \\
\text { before 10 days of } \\
\text { age } \\
(\%)\end{array}$ \\
\hline Cooperative farm & 101 & 64 & 63.4 & 18.2 \\
\hline Stuck farm & 351 & 267 & 76.1 & 14.8 \\
\hline Pasture & 895 & 643 & 73.0 & 13.1 \\
\hline
\end{tabular}


In particular, the proportion of goat kids that died before the age of 10 days was 13.1 to $18.2 \%$. The raising rate of goat kids was different with litter size (Table 5).

Table $5 . \quad$ Raising rate according to litter size

\begin{tabular}{c|c|c|c|c}
\hline Division & Population & Survival & Raising rate (\%) & $\begin{array}{c}\text { Mortality rate } \\
\text { before 10 days of } \\
\text { age (\%) }\end{array}$ \\
\hline Singleton & 484 & 358 & 74.0 & 11.9 \\
\hline $\begin{array}{c}\text { Twin } \\
\text { embryos }\end{array}$ & 396 & 275 & 69.4 & 13.5 \\
\hline Triplets & 15 & 10 & 66.7 & 13.9 \\
\hline
\end{tabular}

As shown in Table 5, the rate of raising goat kids has a constant relationship with litter size, and the higher the litter number, the lower the rate of raising a kid.

\subsection{Serum immunogloblin content of the goat kids and serum turbidity}

In order to reveal the variability characteristics of serum Ig in newborn goat kids, Ig content was analyzed and evaluated and the relationship between Ig concentration and serum turbidity was newly explained.

(1) Serum immunogloblin (Ig) content

The results of quantitative analysis of the serum immunogloblin (Ig) content of the kids after the colostrum intake are as follows.

Table 6. Serum immunogloblin (Ig) content $(\mathrm{mg} / \mathrm{mL})$ of newborn goat kids

\begin{tabular}{c|c|c|c|c|c|c}
\hline \multirow{2}{*}{ Sex } & \multirow{2}{*}{ Population } & \multirow{2}{*}{$\begin{array}{c}\text { Total serum } \\
\text { protein }\end{array}$} & \multicolumn{4}{|c}{ Ig } \\
\cline { 4 - 7 } & & & $\mathrm{M} \pm \mathrm{m}$ & $\delta$ & $\mathrm{C} \%$ & $\mathrm{~L}_{1}^{\sim} \mathrm{L}_{2}$ \\
\hline Male & 17 & 53.5 & $11.70 \pm 0.91$ & 3.74 & 32.0 & $0 \sim 22.61$ \\
\hline Female & 19 & 52.2 & $11.60 \pm 0.83$ & 3.60 & 31.0 & $0 \sim 21.30$ \\
\hline Average & 36 & 53.3 & $11.65 \pm 0.60$ & 3.62 & 31.1 & $0 \sim 22.61$ \\
\hline
\end{tabular}

Ig content did not show significant differences depending on sex and was similar. Analysis of the distribution of population by Ig content shows the following (Table 7).

Table 7. Distribution of population by Ig content

\begin{tabular}{c|c|c}
\hline $\operatorname{Ig}(\mathrm{mg} / \mathrm{mL})$ & Population & Rate (\%) \\
\hline $15.4^{\sim} 22.5$ & 6 & 16.7 \\
\hline $8.0^{\sim} 15.3$ & 24 & 66.7 \\
\hline $7.9^{\sim} 0.8$ & 4 & 11.1 \\
\hline $0.7^{\sim} 0$ & 2 & 5.5 \\
\hline
\end{tabular}

As shown in table 7, the Ig content of the serum tended to be normally distributed around the average value of 11.65 . 
(2) Turbidity of serum immunogloblin

Table 8. Relationship between concentration of an anhydrous sodium sulphate solution and serum turbidity

\begin{tabular}{c|c|c|c|c}
\hline \multirow{2}{*}{ No } & Ig content & \multicolumn{3}{|c}{ Concentration of anhydrous sodium sulphate solution } \\
\cline { 3 - 5 } & $\mathrm{mg} / \mathrm{mL}$ & $14 \%$ & $16 \%$ & $18 \%$ \\
\hline 18 & 0 & - & - & - \\
\hline 32 & 11.60 & - & + & H \\
\hline 12 & 25.10 & - & $\mathrm{H}$ & H \\
\hline
\end{tabular}

The test results in table 8 showed that $14 \%$ of the anhydrous sodium sulphate solution was unreasonable for the turbidity test.

The results of the assessment of the level of turbidity score by Ig content of the serum are as follows to determine the concentration of the anhydrous sodium sulphate.

Table 9. Turbidity score by serum Ig content

\begin{tabular}{c|c|c|c}
\hline \multirow{2}{*}{ No } & \multirow{2}{*}{$\begin{array}{c}\text { Ig content } \\
(\mathrm{mg} / \mathrm{mL})\end{array}$} & $16 \%$ & $18 \%$ \\
\cline { 3 - 4 } & 21.0 & 2 & 2 \\
\hline 2 & 17.7 & 1 & 2 \\
\hline 3 & 16.8 & 2 & 2 \\
\hline 6 & 16.3 & 2 & 2 \\
\hline 8 & 13.6 & 1 & 2 \\
\hline 9 & 12.3 & 2 & 1 \\
\hline 10 & 7.9 & 1 & 1 \\
\hline 11 & 6.3 & 1 & 1 \\
\hline 16 & 1.3 & 1 & 0 \\
\hline 17 & 0 & 0 & \\
\hline 18 & & &
\end{tabular}

As shown in table 9, the assessment score of the turbidity was different depending on the concentration of anhydrous sodium sulphate solution.

The results of the analysis of the relationship between serum Ig content and turbidity of the goat kids are shown in table 10.

Table 10. Serum Ig content according to the level of turbidity $(\mathrm{mg} / \mathrm{mL})$

\begin{tabular}{c|c|c|c|c|c}
\hline Turbidity & Population & $\begin{array}{c}\text { Ig content } \\
\mathrm{M}\end{array}$ & $\delta$ & $\mathrm{C}(\%)$ & $\mathrm{L}_{1} \sim \mathrm{L}_{2}$ \\
\hline 0 & 2 & 0.3 & 0.05 & 16.7 & $0 \sim 0.7$ \\
\hline 1 & 4 & 4.3 & 1.1 & 25.6 & $0.8 \sim 8.0$ \\
\hline 2 & 30 & 15.3 & 4.3 & 28.1 & $8.1 \sim 22.6$ \\
\hline
\end{tabular}

As shown in Table 10, the population with a degree of 0 is within the range of $\operatorname{Ig} 0-0.7 \mathrm{mg}$, and the population with a degree of 1 is found between Ig $0.8-8.0 \mathrm{mg}$, and the population with a degree of 2 is between Ig 8.1$22.61 \mathrm{mg}$. 
(3) Discriminate analysis of Ig Content by serum turbidity

Table 11 identifies the Ig content of 152 newborn goats with an $18 \%$ of the anhydrous sodium sulphate solution.

Table 11. Serum Ig content differentiation

\begin{tabular}{c|c|c|c|c}
\hline \multirow{2}{*}{ Division } & \multirow{2}{*}{ Population } & Identified by + (2) & \multicolumn{2}{|c}{ Identified by - } \\
\cline { 3 - 5 } & & 112 & 30 & 0 \\
\hline Population & 152 & 73.7 & 19.7 & 6.6 \\
\hline Rate (\%) & 100 & & \\
\hline
\end{tabular}

As shown in Table 11, the proportion of individuals with low serum Ig content is $26.3 \%$, accounting for a considerable share of the group.

According to the analysis and evaluation of the serum Ig content of the newborn goat and its relation to the mother variety, the data shown in Table 12.

Table 12. Relationship between variety of mother goats and serum Ig content of kids

\begin{tabular}{c|c|c|c|c}
\hline $\begin{array}{c}\text { Mother goat vari } \\
\text { ety }\end{array}$ & Population & Identified by + & \multicolumn{2}{|c}{ Identified by - } \\
\cline { 4 - 5 } $\begin{array}{c}\text { native } \\
\text { Breeds }\end{array}$ & 122 & $98(80.3)$ & $17(13.9)$ & $7(5.8)$ \\
\hline Saanen F1 & 30 & $22(73.3)$ & $5(16.7)$ & $3(10.0)$ \\
\hline
\end{tabular}

As shown in Table 12, the variety of mother goats tended to have a certain effect on the serum Ig content of goat kids. ( $※$ The number in parentheses is \%)

The results of an analysis of the relationship between the birth order of the mother goat and the serum Ig content of the kid in a native breeds are as shown in Table 13.

Table 13. Formation of serum Ig content of goat kids by mother's Kindling

\begin{tabular}{c|c|c|c|c|c}
\hline \multirow{2}{*}{$\begin{array}{c}\text { Kindling } \\
\text { time }\end{array}$} & \multirow{2}{*}{ Population } & \multicolumn{2}{|c|}{ Identified by +} & \multicolumn{2}{c}{ Identified by - } \\
\cline { 3 - 6 } & & Population & Rate & Population & Rate \\
\hline First & 20 & 15 & 75.0 & 5 & 25.0 \\
\hline Second & 47 & 39 & 83.0 & 8 & 17.0 \\
\hline Third & 32 & 26 & 81.3 & 6 & 18.7 \\
\hline Forth & 18 & 15 & 83.3 & 3 & 16.7 \\
\hline Fifth & 5 & 5 & 100.0 & 0 & 0 \\
\hline
\end{tabular}

As shown in Table 13, due to the increased number of mother littering, the infant goats born from it tend to have a high serum Ig content. 


\subsection{Relationship between serum turbidity and growth}

In order to determine the relationship between serum turbidity and their growth, the relationship between weaning body weight, growth rate, and disease was investigated and evaluated by the serum turbidity.

(1) Serum turbidity and body weight.

The serum Ig content of the newborn kids is reflected in the turbidity level and can affect the body weight of the kids when it is weaned. The results of the survey and analysis of the body weight of the kids, which was breast-fed at the age of two months, are as shown in Table 14 and Table 15.

Table 14 . Weaning weight of goat kids by serum turbidity $(\mathrm{kg})$

\begin{tabular}{c|c|c|c|c|c}
\hline \multirow{2}{*}{ Sex } & Turbidity & Population & Birth weight & Weaning weight & $\begin{array}{c}\text { Daily growth } \\
\text { weight(g) }\end{array}$ \\
\hline \multirow{3}{*}{ Male } & 0 & 3 & 2.3 & $7.5 \pm 0.5$ & 83.3 \\
\cline { 2 - 6 } & 1 & 11 & 2.6 & $9.1 \pm 0.6$ & 108.3 \\
\cline { 2 - 6 } Female & 2 & 51 & 2.6 & $12.1 \pm 0.3$ & 158.3 \\
\cline { 2 - 6 } & 0 & 4 & 2.4 & $7.3 \pm 0.5$ & 81.7 \\
\hline
\end{tabular}

As shown in Table 14, the average weight of the kids at birth was $2.5 \mathrm{~kg}$, indicating no clear difference depending on the serum level. On the other hand, the weaning weight showed a constant difference depending on the strength of the table.

The results of the test for body weight difference by turbidity strength are as follows (Table 15).

Table 15. Body weight difference test data

\begin{tabular}{c|c|c|c}
\hline \multirow{2}{*}{ Sex } & \multirow{2}{*}{ Division } & \multicolumn{2}{|c}{ Body weight difference $(\mathrm{kg})$} \\
\cline { 2 - 4 } & & 1 & 2 \\
\hline \multirow{2}{*}{ Male } & 0 & 1.6 & $4.6^{* * *}$ \\
\cline { 2 - 4 } & 1 & - & $3.0^{* * *}$ \\
\hline \multirow{2}{*}{ Female } & 0 & 1.1 & $4.4^{* * *}$ \\
\cline { 2 - 4 } & 1 & - & $3.3^{* * *}$ \\
\hline
\end{tabular}

As shown in Table 15, the kids, whose strength was rated 2 for the turbidity, grew faster regardless of gender and were definitely larger in body weight $(\mathrm{P}<0.001)$ than the zero and one.

(2) Serum turbidity and growth rate

Among the goat kids that ate the colostrum, the kids with low serum level had a poor rate of growth (Table 16).

Table 16. Serum turbidity and raising rate of goat kids

\begin{tabular}{c|c|c|c|c}
\hline Turbidity & Population & Survival & Raising rate (\%) & $\begin{array}{c}\text { Dead number per } \\
100 \text { goats }\end{array}$ \\
\hline 0 & 10 & 7 & 70.0 & 30 \\
\hline 1 & 30 & 22 & 73.3 & 27 \\
\hline 2 & 112 & 97 & 86.6 & 13 \\
\hline Average & 152 & 126 & 82.9 & 17 \\
\hline
\end{tabular}


As shown in Table 16, the rate of raising goat kids by turbidity was $70 \%, 73.3 \%$ and $86.6 \%$ respectively, and the higher the level of turbidity, the higher the rate of raising the goat kids.

(3) Blood serum turbidity and rate of occurrence of diseases

Table 17. The incidence of diseases in goat kids

\begin{tabular}{c|c|c|c}
\hline Turbidity & Population & Diarrhea & Respiratory disease \\
\hline 0 & 7 & $5(71.4)$ & $1(14.3)$ \\
\hline 1 & 22 & $14(63.6)$ & $4(18.2)$ \\
\hline 2 & 97 & $11(11.3)$ & $7(7.2)$ \\
\hline
\end{tabular}

※ Numbers in parentheses indicate the incidence.

As shown in Table 17, individuals with low turbidity had a relatively high incidence of diarrhea and respiratory diseases due to their low resistance.

\section{DISCUSSION}

The immunogloblin of serum, which is based on raising a goat kids, plays an important biological role in enhancing the immunity of organisms and ensuring the balance of nutrients. Body weight is a basic indicator of how young goats are raised. The weight at birth of the goat kids greatly influences its body weight size and raising rate in the future.The body weight of a native breeds ranged from 2.3 to 2.4 $\mathrm{kg}$, but the body weight reached 3.0 to $3.2 \mathrm{~kg}$ in the Saanen goat. His F1 goats had a birthweight of 2.5 to $2.7 \mathrm{~kg}$, larger than native breed and smaller than Saanen. The rate of raising goat kids was 74 percent in singleton, but 69.4 percent in twin embryos and 66.7 percent in triplets. The serum Ig content of the newborn goat at colostrum averaged $11.65 \mathrm{mg}$ per $\mathrm{ml}$ of serum and did not vary significantly depending on the number of females. There were $31.1 \%$ variations in Ig content, and some individuals had no Ig at all. On the other hand, the healthy individual had an $\mathrm{Ig}$ of $22.6 \mathrm{mg}$. According to the distribution of population by Ig content, between 0 and $0.7 \mathrm{mg}$ was $5.5 \%$ and 0.8 to $7.9 \mathrm{mg}$ was $11.1 \%$. We have introduced a new method for evaluating the level of turbidity that easily tests serum Ig in field conditions. An 18\% solution of anhydrous sodium sulphate ensured the accuracy of the Ig test. There were three types of basalt levels of serum-anhydrous sodium sulphate solution, which were marked with 0,1 , and
2 , respectively. The percentage of population with low Ig content was $26.3 \%$, of which 0 was $6.6 \%$ and 1was $9.7 \%$ respectively. According to the test of 152 hybrid breeds of the native and Saanen breeds, 0 was $6.7 \%$ and 1 was $14.5 \%$. In addition, the relationship between serum turbidity and growth of the goat kids was newly assessed by linking it with body weight and rate of growth. The goat kids, whose level was rated as zero, had a weaning weight of 7.3 to $7.5 \mathrm{~kg}$, which was the smallest compared to 11.7 to $12.1 \mathrm{~kg}$ at the 2 turbidity $(\mathrm{P}<0.001)$. The growth rate of the goat kids was $70,73.3$ and $86.6 \%$, respectively, for each level, which was much higher in the population which was rated at 2 . In addition, individuals with low level of suspension were less adaptable to the living environment, so the frequency of diarrhea and respiratory diseases was high.

\section{CONCLUSION}

Goat grows quickly and produces a lot of meat and milk, so the problem of goat breeding and management is important, and it is also very important to scientifically manage the specification for goat kids. We established a methodological basis for easily examining serum immunogloblin content in newborn goat kids at an early age and establishing necessary livestock measures. The serum immunogloblin content of the newborn goat kids, which ate the colostrum, is $11.65 \mathrm{mg}$ per $\mathrm{ml}$ of serum on average and is highly individual-specific 
variability. The serum immunogloblin of the goat kids can be tested in field conditions by the degree of preference of the use of an anhydrous sodium sulphate solution, and by establishing necessary measures, can be improved the practicality of goat raising. The serum turbidity is closely related to the weaning weight and growth rate of the kids, with an average body weight of more than $10 \mathrm{~kg}$, the average daily body weight of $150 \mathrm{~g}$, and the rate of raising $86.6 \%$, the higher the turbidity score, the higher the rate of growth.

\section{REFERENCES}

[1]. Getaneh G, Mebrat A, Wubie A. Review on Goat Milk Composition and its Nutritive Value. Journal of Nutrition and Health Sciences. 2016, 3(4): 1-11.

[2]. Kaneko. J. J. Clinical Biochemistry of Domestic Animals. 2001, 1-52.

[3]. Harish Kumar, Devbrat Yadav, Naveen Kumar. Nutritional and nutraceutical properties of goat milk-A review. Indian J Dairy Sci. 2016, 69(5): 513-518.

[4]. M. Mellado, W. Pittroff. Serum IgG, blood profiles, growth and survival in goat kids supplemented with artificial colostrum on the first day of life. Trop Anim Health Prod. 2008, 40: 141-145.

[5]. Schmidt. G. H. Biology of Lactation. 1997, 2129.

[6]. Hayam M. Abbas, Fatma A.M. Hassan. Physicochemical Characteristics of Goat's Milk. Life Science Journal 2014, 11(1s): 307-317.

[7]. Sandra G. Solaiman. Goat Science and Production. 2010, 275-290.

[8]. J.P.O'Brien, D.M.Shermana. Serum immunoglobulin concentrations of newborn goat kids and subsequent kid survival through weaning. Small Ruminant Research. 1993, 11(1): 71-77.

[9]. Abel Francisco, S.F, Quigley, J.D. Serum immunoglobulin concentrations after feeding maternal colostrum or maternal colostrum plus colostral supplement to dairy calves. Am. J. Vet. Res. 1993, 54: 1051-1054.

[10]. Sherman, D.M. Comparing the effects of four colostral preparations on serum Ig levels of newborn kids .Veterinary medicine. 1990, 85: 908-913.

\section{Cite this article as :}

Jin MyongIl, Choe SunIl, Kim YunChol, Ri SongGil, Kim MyongGuk, Hong SongDu, Ra KiChol, "Test of Serum Immunoglobulin (Ig) of Newborn Kids by Anhydrous Sodium Sulphate", International Journal of Scientific Research in Science, Engineering and Technology (IJSRSET), Online ISSN : 2394-4099, Print ISSN : 2395-1990, Volume 8 Issue 1, pp. 65-74, January-February 2021. Available at doi : https://doi.org/10.32628/IJSRSET218110 Journal URL : http://ijsrset.com/IJSRSET218110 